\title{
Productive Performance of Chestnut Trees for Cultivation in Tropical Regions
}

\author{
Dayanne Medrado Silva ${ }^{1}$, Rafael Pio ${ }^{1}$, Daniela da Hora Farias ${ }^{1}$, Evaldo Tadeu de Melo ${ }^{1}$ \\ \& Pedro Maranha Peche ${ }^{1}$ \\ ${ }^{1}$ Department of Agriculture, University of Lavras, Lavras, MG, Brazil \\ Correspondence: Daniela da Hora Farias, Department of Agriculture, University of Lavras, 37200-000, Lavras, \\ MG, Brazil. E-mail: dhorafarias@gmail.com
}

Received: January 27, 2019

Accepted: March 15, 2019 Online Published: May 15, 2019

doi:10.5539/jas.v11n6p183

URL: https://doi.org/10.5539/jas.v11n6p183

\begin{abstract}
Chestnut trees are economically exploited in temperate regions of Asian countries, Oceania and the European Iberian Peninsula. Chestnuts are sources of protein and carbohydrates and are eaten in many ways, mainly roasted during cold temperatures. Chestnuts may be suitable for cultivation in tropical regions, but to do this, the potential cultivars' productive performances should be quantified. Thus, this study determined the performances of chestnut cultivars in a tropical region using the Taishowase, Isumo, Tamatsukuri and Okuni cultivars. The cultivars' phenological development, including the beginning and end of flowering and harvesting, as well as each cultivar's nut production were evaluated over four production cycles. The Taishowase and Okuni cultivars were shown to be the most promising for tropical regions because they showed greater adaptability and production stability.
\end{abstract}

Keywords: Castanea spp., productivity, genotype $\times$ environment interaction

\section{Introduction}

Chestnut trees belong to the Fagaceae family and the Castanea genus, which comprises seven species, including C. sativa Miller, C. crenata Siebold \& Zucc., C. molissima Blume and C. dentata (Marsh.) Borkh. (Bueno \& Pio, 2014). These species were named for their place of origin and are known as the Portuguese chestnut (Portugal), Japanese chestnut (Japan and South Korea), Chinese chestnut (China) and American chestnut (North America), respectively (Yamanishi et al., 2010).

Chestnuts are widely enjoyed for their nutritional characteristics, especially in countries with temperate climates (Kan et al., 2017; Benedetti et al., 2018). Chestnuts contain high-quality protein and little fat (3\% of the total weight) and are gluten-free. They also contain vitamin C, potassium, low sodium and approximately $45 \%$ starch, in addition to fatty acids, which can vary among species and cultivars (Pio et al., 2014).

In South America, chestnuts are mainly imported from Portugal (98.5\%), with a small percentage from Spain $(1.5 \%)$ (Bueno \& Pio, 2014). Chestnut trees require mild climate and adequate moisture for growth and good productivity (Muzaffar et al., 2016). When exposed to high temperatures, they reduce their photosynthetic activity by $60 \%$ during the day (Gomes-Laranjo et al., 2006), demonstrating their potential for cultivation in tropical regions. In regions with higher temperatures, the chestnuts' antioxidant activity is decreased (Dinis et al., 2012), but no other losses in chemical properties, such as sugars or proteins, are observed (Pio et al., 2014).

Production of temperate fruit trees in tropical regions is challenging due to the low cooling conditions, but some cultivars have lower thermal requirements; thus, cultivars must be selected for each macroregion (Pio et al., 2019). Some commercial orchards in the highlands in Brazil demonstrate potential for cultivating Castanea crenata $\times$ Castanea sp. hybrids (Pio et al., 2017), but no data exist in the literature on chestnut production in tropical regions.

To select more stable individuals with higher productive performances, studies on the genotype $\times$ environment (GE) interaction play important roles in determining a genotype's adaptation and suitability to the environment and thus may aid in selecting chestnut cultivars for tropical regions. Therefore, this study determined the performance of chestnut cultivars in a tropical region. 


\section{Method and Methods}

The study was conducted in the municipality of Lavras, Minas Gerais state, Brazil, located at $21^{\circ} 14^{\prime}$ south latitude and $45^{\circ} 00^{\prime}$ west longitude, at an average altitude of 918 metres, from September 2011 to February 2018. Based on the Köppen classification, the regional climate is type $\mathrm{Cwb}$ (mesothermal or tropical highland climate), with dry winters and rainy summers.

Seedlings aged 15 months from the Taishowase, Isumo, Tamatsukuri and Okuni cultivars and grafted on Taishowase rootstock were acquired from a commercial nursery and planted in the field in September 2011, spaced $4 \mathrm{~m}$ between rows and $5 \mathrm{~m}$ between trees (density of 500 trees per hectare). The experiment was conducted in randomized blocks, containing four treatments (cultivars), with five blocks and two useful trees per experimental unit.

Throughout the experiment, weeds were controlled in the experimental area, and compost ( $3 \mathrm{~L}$ per tree) was applied twice, once in June and once in November of each cultivation year. The compost was a 3:1 mixture of decomposed plant material to cattle manure. Soil was analysed during the four cultivation years, revealing the following parameter values: $5.7 \mathrm{pH}, 46.3 \mathrm{~g} \mathrm{dm}^{-3}$ organic matter, $136.9 \mathrm{mg} \mathrm{dm}^{-3}$ phosphorus, $10.1 \mathrm{mmolc} . \mathrm{dm}^{-3}$ calcium, $3.1 \mathrm{mmolc} \mathrm{dm}^{-3}$ magnesium, $14.2 \mathrm{sum}$ of bases and 15.5 cation exchange capacity. For plant maintenance, $300 \mathrm{~g}$ of ammonium sulphate was applied, divided into two applications (one in October and one in January), plus $200 \mathrm{~g}$ of simple superphosphate and $200 \mathrm{~g}$ of potassium chloride applied in September and $150 \mathrm{~g}$ of lime per plant applied in May.

In the 2014/15, 2015/16, 2016/17 and 2017/18 production cycles, the chestnut cultivars' phenology was described, including the beginning and end of flowering and harvesting. The flowering and harvesting durations were calculated in days. To quantify the productive performance during the four production cycles, the cupules were harvested every four days per plot, and the nuts were removed, counted and weighed. The total number of nuts, mean nut weight, production ( $\mathrm{kg}$ tree) and estimated yield $\left(\mathrm{kg} \mathrm{ha}^{-1}\right.$, considering a density of 500 trees per ha) were calculated at the end.

The interaction between years and cultivars was viewed using the genotype and genotype $\times$ environment (GGE) biplot method (genotype main effect and genotype by environment interaction) as described by Yan et al. (2000) and analysed per Oliveira et al. (2010) using the R program, considering the simplified model of two principal components (Equation 1):

$$
\bar{Y}_{\mathrm{ij}}-\mu_{\mathrm{j}}=\lambda_{1} \gamma_{\mathrm{i} 1} \alpha_{\mathrm{j} 1}+\lambda_{2} \gamma_{\mathrm{i} 2} \alpha_{\mathrm{j} 2}+\rho_{\mathrm{ij}}+\bar{\varepsilon}_{\mathrm{ij}}
$$

where, $\lambda_{1} \gamma_{i 1} \alpha_{j 1}$ is the first principal component (PCA1) of the effect of the genotypes $(\mathrm{G})+$ the interaction $(\mathrm{G} \times \mathrm{E}) ; \lambda_{2} \gamma_{\mathrm{i} 2} \alpha_{\mathrm{j} 2}$ is the second principal component (PCA2) of the effect of the genotypes (G) + the interaction $(\mathrm{G} \times \mathrm{E}) ; \lambda_{1}$ and $\lambda_{2}$ are the eigenvalues associated with PCA1 and PCA2, respectively, and $\gamma_{\mathrm{i} 1}$ and $\gamma_{\mathrm{i} 2}$ are the scores of PCA1 and PCA2, respectively, for the genotypes; $\alpha_{\mathrm{j} 1}$ and $\alpha_{\mathrm{j} 2}$ are the scores of PCA1 and PCA2, concomitantly for the environments; $\rho_{\mathrm{ij}}$ is the residue of the genotype $\times$ environment interaction, corresponding to the principal components not retained in the model; and $\bar{\varepsilon}_{\mathrm{ij}}$ is the residue of the model with normal distribution, zero mean, and variance $\sigma^{2} / \mathrm{r}$ (where $\sigma^{2}$ is the variance of the error between plots for each environment, and $r$ is the number of replications). Statistical analyses were conducted as split plots in time, with time (production cycles) constituting the main plots and the cultivars constituting the split plots.

The data were submitted to analysis of variance, and the averages were compared via Tukey's test $(p \leq 0.05)$ using the Genes Program Software for PCs (Cruz, 2013). Adaptability and stability were analysed using GGE biplot methodology (Yan \& Rajcan, 2002), and the graphs were generated using R Program software for PCs.

\section{Results and Discussion}

In the first production cycle (2014/15), the flowering began in the second half of July and ended in early October, and harvesting began in the first half of November until the end of January of the following year (Table 1). The flowering period duration was very short in the Isumo cultivar, which flowered between the beginning of August and the second half of September, leading to a short harvest period (45 days). This finding evidences this cultivar's lack of adaptation to mild winter climatic conditions. 
Table 1. Phenological description: beginning the flowering (BF), end the flowering (EF), duration of flowering (DF), beginning harvest $(\mathrm{BH})$, end the harvest $(\mathrm{EH})$, duration of harvest $(\mathrm{DH})$ of four chestnut cultivars (Castanea crenata $\times$ Castanea $\mathrm{sp}$.) in four production cycles

\begin{tabular}{|c|c|c|c|c|c|c|}
\hline Cultivars & $\mathrm{BF}$ & $\mathrm{EF}$ & DF (days)* & HB & EH & DH (days)* \\
\hline \multicolumn{7}{|c|}{ Productive year 2014/15 } \\
\hline Taishowase & $20 / 07$ & $08 / 10$ & $80 \mathrm{Ca}$ & $28 / 11$ & $27 / 01$ & $60 \mathrm{Ba}$ \\
\hline Isumo & $01 / 08$ & $20 / 09$ & $50 \mathrm{Bb}$ & $21 / 11$ & $05 / 01$ & $45 \mathrm{Aa}$ \\
\hline Tamatsukuri & $23 / 07$ & $25 / 09$ & $64 \mathrm{Bab}$ & $20 / 11$ & $22 / 01$ & $63 \mathrm{ABa}$ \\
\hline Okoni & $03 / 08$ & $16 / 09$ & $75 \mathrm{Ba}$ & $07 / 11$ & $12 / 01$ & $66 \mathrm{ABa}$ \\
\hline \multicolumn{7}{|c|}{ Productive year 2015/16 } \\
\hline Taishowase & $20 / 07$ & $11 / 11$ & $114 \mathrm{Ba}$ & $26 / 11$ & $27 / 01$ & $63 \mathrm{Ba}$ \\
\hline Isumo & $05 / 08$ & $19 / 10$ & $75 \mathrm{Bbc}$ & $20 / 11$ & $22 / 12$ & $52 \mathrm{Aa}$ \\
\hline Tamatsukuri & $23 / 07$ & $22 / 09$ & $61 \mathrm{Bc}$ & $12 / 11$ & $23 / 01$ & $72 \mathrm{ABa}$ \\
\hline Okoni & $30 / 07$ & $01 / 11$ & $95 \mathrm{Aab}$ & $18 / 11$ & $26 / 01$ & $69 \mathrm{ABa}$ \\
\hline \multicolumn{7}{|c|}{ Productive year 2016/17 } \\
\hline Taishowase & $15 / 08$ & $23 / 11$ & $100 \mathrm{BCa}$ & $22 / 11$ & $30 / 03$ & $130 \mathrm{Aa}$ \\
\hline Isumo & $23 / 08$ & $24 / 10$ & $63 \mathrm{Bb}$ & $22 / 11$ & $13 / 01$ & $53 \mathrm{Ab}$ \\
\hline Tamatsukuri & $19 / 08$ & $19 / 10$ & $61 \mathrm{Bb}$ & $05 / 11$ & $23 / 01$ & $80 \mathrm{Bb}$ \\
\hline Okoni & $23 / 08$ & $08 / 11$ & $78 \mathrm{Bb}$ & $05 / 11$ & $02 / 02$ & $90 \mathrm{Bb}$ \\
\hline \multicolumn{7}{|c|}{ Productive year 2017/18 } \\
\hline Taishowase & $20 / 07$ & $13 / 02$ & $182 \mathrm{Aa}$ & $30 / 11$ & $09 / 04$ & $130 \mathrm{Aa}$ \\
\hline Isumo & $13 / 07$ & $10 / 11$ & $120 \mathrm{Ab}$ & $17 / 11$ & $26 / 01$ & $72 \mathrm{Ab}$ \\
\hline Tamatsukuri & $13 / 07$ & $30 / 10$ & $109 \mathrm{Ab}$ & $20 / 08$ & $23 / 11$ & $95 \mathrm{Ab}$ \\
\hline Okoni & $13 / 07$ & $21 / 10$ & $101 \mathrm{Ab}$ & $17 / 11$ & $18 / 02$ & $93 \mathrm{Ab}$ \\
\hline CV (\%) Subplots & & & 13.2 & & & 28.6 \\
\hline CV (\%) Plots & & & 13.3 & & & 28.1 \\
\hline
\end{tabular}

Note. * Uppercase letters compare the production cycles, and lowercase letters compare the cultivars; means followed by the same uppercase or lowercase letters do not differ significantly by Tukey's means comparison test $(\mathrm{P} \leq 0.05)$.

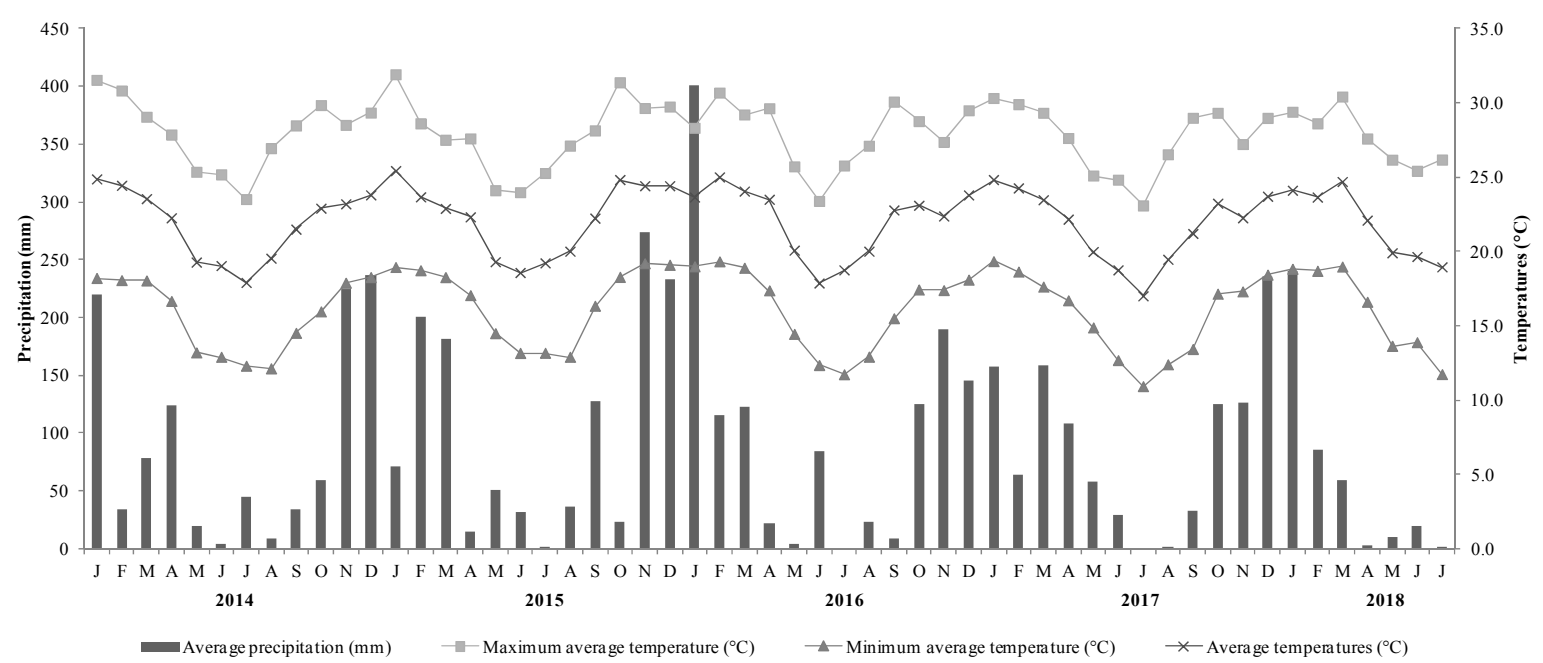

Figure 1. Mean minimum and maximum temperatures and cumulative rainfall for the production cycles

In the second production cycle (2015/16), flowering began early and was concentrated between the end of July and beginning of August (Table 1). The early flowering may have been due to the trees' maturity or the climate because during the production cycle, the mean maximum temperatures were higher for July and August (Figure 1). Consequently, the harvest period was extended and continued until the end of January in the Taishowase and Okuni cultivars. Per Medina Mora et al. (2018), chestnut cultivar flowering periods naturally vary between years. 
In the third production cycle (2016/17), all cultivars began flowering late in the second half of August (Table 1). However, the Taishowase and Okuni cultivars showed a greater flowering range. Harvesting these cultivars began in November and persisted until the end of the last half of March. A prolonged flowering period may not favour cultivar development because of the greater exposure to climatic adversities such as temperature drops and water deficit (Souza et al., 2013).

In the fourth production cycle (2017/18), flowering began early (Table 1). The end of the flowering period was more prolonged, which helped increase the flowering duration, which persisted between 101 days (Okuni) and 182 days (Taishowase). The beginning of the harvest period varied by cultivar, with the earliest cultivar harvest (Tamatsukuri) beginning in the second half of August and the latest cultivar harvest (Taishowase) at the end of November. Pio et al. (2014) studied the dehiscence and beginning and end of the harvest for different chestnut cultivars in highland regions and found that the Tamatsukuri cultivar was considered an early cultivar whose harvest began in the second half of October. Notably, the late cultivar Taishowase showed the same behaviour in all evaluated production cycles, with harvesting always beginning in the second half of November. This finding evidences the Taishowase cultivar's adaptation to the edaphoclimatic conditions of tropical regions. This longer harvesting period is important because hot summers and climatic events, such as excessive rains, concentrated at the end of the year can damage fruits and impair harvests, as occurred in the production cycles (Figure 1).

During the chestnut's annual cycle, flowering is the most critical phase. Chestnuts are monoecious, with staminate (male) and pistillate (female) flowers on the same tree (Vossen, 2000). Mixed catkins sprout from the one-year-old lignified branches. Staminate catkins grow from the basal shoot, while bisexual catkins grow more towards the shoot tip. These bisexual catkins will have one to three pistillate flowers at their bases, with the remaining flowers being staminate. Each pistillate flower differentiates into three pistils. If pollinated and fertilized, the ovaries of all three will developed flattened nuts; if only one is pollinated, a larger, rounder nut will develop (Pio, 2018).

Under the tropical conditions in Brazil, chestnut trees begin flowering in late winter and the beginning of spring based on the species and cultivar (Pio, 2018). Some cultivars may release pollen before the pistillate flowers are receptive, requiring cross-pollination (Medina Mora et al., 2018). Thus, pollinator trees must be cultivated and appropriately arranged in the orchard with a fully or partially synchronized flowering period to obtain satisfactory productivity.

Thus, given the overlapping flowering period, the Okuni cultivar can be used as a pollinator and Taishowase as a commercial cultivar in commercial chestnut orchards. Of note, flowering periods may vary depending on the year, place, farming practices and, especially, edaphoclimatic conditions. In addition, these cultivars are richer in potassium, boron and copper, and the Okuni cultivar has more protein in relation to other cultivars when grown in subtropical climates (Pio et al., 2014).

Regarding the productive performance variation in the evaluated production cycles (Table 2), the Taishowase cultivar differed significantly in the mean number of nuts in all cycles, followed by the Tamatsukuri cultivar, which reached its best potential in the 2017/18 cycle. The Okuni cultivar had the highest mean nut weight in all production cycles, followed by the Isumo cultivar in the 2016/17 and 2017/18 cycles. Mean nut weight is an important criterion in cultivar selection (Zenginbal et al., 2018). In this sense, the Okuni, Tamatsukuri and Isumo cultivars presented higher mean nut weights over the production cycles, although all cultivars exceeded a mean of 5 to $10 \mathrm{~g}$, as discussed by Zenginbal et al. (2018).

For the variables production per tree and estimated yield, the Taishowase cultivar obtained the best productive performance, production of $5.2 \mathrm{~kg}$ of nuts per tree and an estimated yield of $2,585.7 \mathrm{~kg} \mathrm{ha}^{-1}$ for all study cycles, followed by the Tamatsukuri and Okuni cultivars in only the 2017/18 cycle.

Vossen (2000) indicated that pollen patterns can influence pollinated nuts, especially regarding fruit weight, due to the xenia phenomenon. That is, pollen from a tree with well-developed nuts can alter its receptor's genetic characteristics, leading to qualitative and quantitative changes in nut size. Thus, the finding that the Okuni cultivar's mean nut weight excelled across all the production cycles reinforces the indication for using this cultivar as a pollinator in commercial orchards. 
Table 2. Total number of nuts, mean nut weight, production $(\mathrm{kg} / \mathrm{tree})$ and estimated yield $(\mathrm{kg} / \mathrm{ha})$ of four chestnut cultivars (Castanea crenata $\times$ Castanea $\mathrm{sp}$.) in four production cycles

\begin{tabular}{|c|c|c|c|c|c|}
\hline Cultivars & $2014 / 15$ & $2015 / 16$ & $2016 / 17$ & $2017 / 18$ & General average** \\
\hline \multicolumn{6}{|c|}{ Total number of nuts* } \\
\hline Taishowase & $189.6 \mathrm{Da}$ & $290.8 \mathrm{Ca}$ & $508.4 \mathrm{Ba}$ & $596.2 \mathrm{Aa}$ & $396.3 \mathrm{a}$ \\
\hline Isumo & $37.4 \mathrm{Bb}$ & $27.4 \mathrm{Bc}$ & $19.2 \mathrm{Bc}$ & 207.2 Ac & $72.8 \mathrm{~d}$ \\
\hline Tamatsukuri & $71.4 \mathrm{Bb}$ & $84.2 \mathrm{Bb}$ & $57.0 \mathrm{Bbc}$ & $563.2 \mathrm{Aa}$ & $194.0 \mathrm{~b}$ \\
\hline Okuni & $46.8 \mathrm{Bb}$ & $52.6 \mathrm{Bbc}$ & $100.4 \mathrm{Bb}$ & $377.2 \mathrm{Ab}$ & $144.3 \mathrm{c}$ \\
\hline CV (\%)Subplots & 13.3 & & & & \\
\hline CV (\%) Plots & 14.8 & & & & 16.5 \\
\hline \multicolumn{6}{|c|}{ Mean nut weight (g) } \\
\hline Taishowase & $10.6 \mathrm{Ac}$ & $11.8 \mathrm{Ac}$ & $13.2 \mathrm{Ab}$ & $14.2 \mathrm{Ab}$ & $12.5 \mathrm{a}$ \\
\hline Isumo & 17.2 Aab & 18.0 Aab & $19.0 \mathrm{Aa}$ & $19.4 \mathrm{Aa}$ & $18.4 \mathrm{a}$ \\
\hline Tamatsukuri & $14.8 \mathrm{Ab}$ & $15.2 \mathrm{Ab}$ & $15.6 \mathrm{Ab}$ & $16.0 \mathrm{Ab}$ & $15.4 \mathrm{a}$ \\
\hline Okuni & $20.0 \mathrm{Aa}$ & $20.6 \mathrm{Aa}$ & $20.8 \mathrm{Aa}$ & $21.8 \mathrm{Aa}$ & $20.8 \mathrm{a}$ \\
\hline CV (\%)Subplots & 10.3 & & & & \\
\hline CV (\%) Plots & 17.5 & & & & 2.9 \\
\hline \multicolumn{6}{|c|}{ Production (kg tree) } \\
\hline Taishowase & $2.0 \mathrm{Ba}$ & $3.5 \mathrm{Ba}$ & 6.6 Aa & 8.6 Aa & $5.2 \mathrm{a}$ \\
\hline Isumo & $0.6 \mathrm{Bb}$ & $0.5 \mathrm{Bb}$ & $0.4 \mathrm{Bc}$ & 4.0 Ab & $1.4 \mathrm{~b}$ \\
\hline Tamatsukuri & 1.1 Bab & $1.3 \mathrm{Bb}$ & $0.9 \mathrm{Bbc}$ & $9.0 \mathrm{Aa}$ & $3.1 \mathrm{ab}$ \\
\hline Okuni & $0.9 \mathrm{Bab}$ & $1.1 \mathrm{Bb}$ & $2.1 \mathrm{Bb}$ & $8.3 \mathrm{Aa}$ & $3.1 \mathrm{ab}$ \\
\hline CV (\%)Subplots & 23.0 & & & & \\
\hline CV (\%) Plots & 26.1 & & & & 26.9 \\
\hline \multicolumn{6}{|c|}{ Estimated yield $\left(\mathrm{kg} \mathrm{ha}^{-1}\right)$} \\
\hline Taishowase & $1006.9 \mathrm{Ba}$ & $1752.6 \mathrm{Ba}$ & $3300.4 \mathrm{Aa}$ & $4282.9 \mathrm{Aa}$ & $2585.7 \mathrm{a}$ \\
\hline Isumo & $316.9 \mathrm{Bb}$ & $247.7 \mathrm{Bb}$ & $182.6 \mathrm{Bc}$ & $2010.5 \mathrm{Ab}$ & $689.4 \mathrm{c}$ \\
\hline Tamatsukuri & $530.2 \mathrm{Bab}$ & $640.9 \mathrm{Bb}$ & $444.8 \mathrm{Bc}$ & $4496.0 \mathrm{Aa}$ & $1528.0 \mathrm{~b}$ \\
\hline Okuni & 466.6 Bab & $547.8 \mathrm{Bb}$ & $1046.1 \mathrm{Bb}$ & $4142.6 \mathrm{Aa}$ & $1550.8 \mathrm{~b}$ \\
\hline CV (\%)Subplots & 23.0 & & & & \\
\hline CV (\%) Plots & 26.1 & & & & 26.9 \\
\hline
\end{tabular}

Note. * Means followed by the same uppercase letter in a row and lowercase letter in a column do not differ significantly by Tukey's means comparison test $(\mathrm{P} \leq 0.05)$.

** Means followed by the same letter do not differ significantly by Tukey's means comparison test $(\mathrm{P} \leq 0.05)$.

The GGE biplot was analysed for the estimated yield data of the different chestnut cultivars, using principal components and the modified centroid method (Figure 2). Figure 2A illustrates the best genotype performance over the years (i.e., 'which-won-when'). Yan and Kang (2003) proposed the polygon view of a biplot to visualize the genotype and environment interaction. The genotype in the vertex of the polygon is the winner in the years falling in this sector. The lines perpendicular to each side of the polygon are lines of equality between adjacent genotypes (Yan \& Tinker, 2006). The equality line is useful for comparing genotype performance in a year. For example, the equality line between Tamatsukuri and Taishowase (Figure 2A) indicates that Taishowase was better in all years except 2017/18. Among the three vertex cultivars, Taishowase, Tamatsukuri and Isumo, most production cycles were in the Taishowase cultivar sector, reinforcing this cultivar's performance in most of the years evaluated. 
A

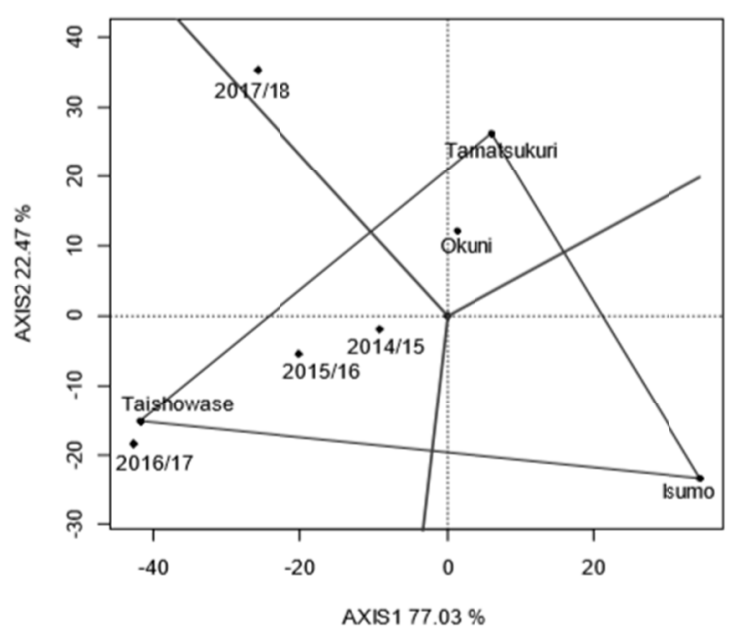

B

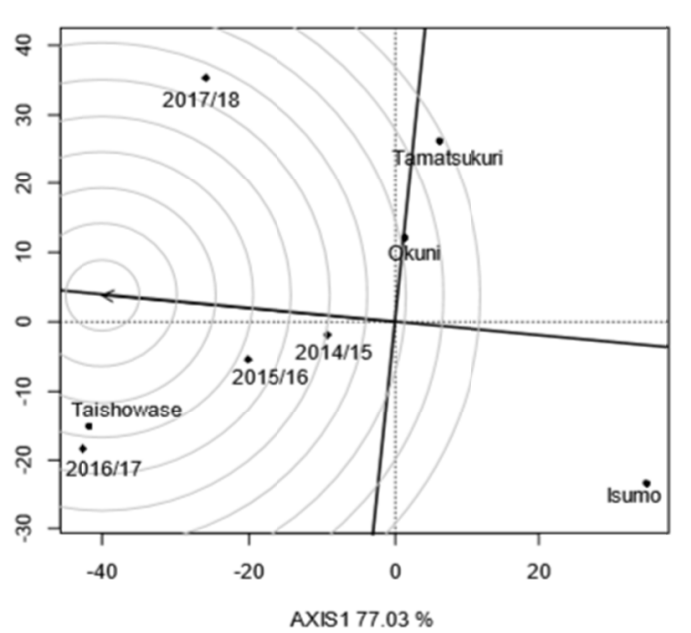

Figure 2. GGE biplot showing the winning genotypes relative to production years (A) and comparison of genotypes with the ideal genotype (B)

Subsequently, the cultivars' adaptability and stability regarding estimated yield was evaluated based on their distances from the "ideal genotype" (Figure 2B). The centre of the concentric circles represents the ideal genotype position (Yan \&Tinker, 2006). The Taishowase and Okuni cultivars are closer to the concentric circle; therefore, they are considered the most desirable in terms of average performance and yield stability. Conversely, Isumo was farthest from the ideal genotype position, thus being the most unstable.

Under mild winter conditions, cultivars from temperate regions can vary greatly from one cycle to another in their flowering period and productive performance, which can be attributed to the instability of biotic and edaphoclimatic factors during the cycle, characteristic of tropical regions (Petri et al., 2008; Bettiol Neto et al., 2011). Dinis et al. (2010) suggest that pollination and embryonic growth are strongly influenced by climatic conditions that vary from site to site at different altitudes and over years, often being the main cause of production variability in terms of chestnut tree quantity and quality.

\section{Conclusions}

Chestnut harvesting is concentrated between the first half of November and the second half of April, with Tamatsukuri being the earliest cultivar and Taishowase being the latest.

The Taishowase and Okuni cultivars are the most promising for tropical regions because they showed greater adaptability and productive performance stability.

\section{References}

Benedetti, S., Balocchi, F., Gonzalez, M., \& Garcia-Chevesich, P. (2018). Morphological characterization of sweet chestnut fruits from forest plantations in central Chile. Ciencia e investigación agraria, 45, 138-146. https://doi.org/10.7764/rcia.v45i2.1808

Bettiol Neto, J. E., Pio, R., Sanches, J., Chagas, E. A, Cia, P., \& Chagas, P. C. (2011). Antoniali, S. Production and quality attributes of quince tree cultivars in the eastern of the state of São Paulo. Revista Brasileira de Fruticultura, 33, 1035-1042. https://doi.org/10.1590/S0100-29452011000300042

Bueno, S. C. S., \& Pio, R. (2014). Chestnut in Brazil. Revista Brasileira de Fruticultura, 36, 16-22. https://doi.org/10.1590/0100-2945-442/13

Cruz, C. D. (2013). Genes-A software package for analysis in experimental statistics and quantitative genetics. Acta Scientiarum, 35, 271-276.

Dinis, L. T., Ramos, S., Gomes-Laranjo, J., Peixoto, F., Vallania, R., Costa, R., \& Botta, R. (2010). Phenology and reproductive biology in cultivar 'Judia' (Castanea sativa mill.). Acta Horticulturae, 866, 169-174. https://doi.org/10.17660/ActaHortic.2010.866.19 
Dinis, L. T., Oliveira, M. M., Almeida, J., Costa, R., Gomes-Laranjo, J., \& Peixoto, F. (2012). Antioxidant activities of chestnut nut of Castanea sativa Mill. (cultivar 'Judia') as function of origin ecosystem. Food Chemistry, 132, 1-8. https://doi.org/10.1016/j.foodchem.2011.09.096

Gomes-Laranjo, J., Peixoto, F., Sang, H. W. W. F., \& Torres-Pereira, J. (2006). Study of the temperature effect in three chestnut (Castanea sativa Mill.) cultivars behaviour. Journal of Plant Physiology, 163, 945-955. https://doi.org/10.1016/j.jplph.2005.06.020

Kan, L., Zhao, Q., Hu, J., Wu, Y., \& Ouyang, J. (2017). Synthesis and physicochemical properties of carboxymethyl chestnut starch. Journal of Food Processing and Preservation, 41(6). https://doi.org/ 10.1111/jfpp.13229

Medina Mora, C., Jarosz, A. M., \& Fulbright, D. W. (2018). Studies to determine phenology and pollination in the European $\times$ Japanese hybrid 'Colossal' in Michigan orchards. Acta Horticulturae, 1220, 71-78. https://doi.org/10.17660/ActaHortic.2018.1220.11

Muzaffar, S., Maqbool, K., Wani, I. A., Masoodi, F. A., \& Bhat, M. M. (2016). Physico-Chemical Characterization of Sweet Chestnut (Castanea sativa L.) Starch Grown in Temperate Climate of Kashmir, India. Acta Alimentaria, 45, 258-267. https://doi.org/10.1556/066.2016.45.2.13

Oliveira, R. L, Von Pinho, R. G, Balestre, M., \& Ferreira, D. V. (2010). Evaluation of maize hybrids and environmental stratification by the methods AMMI and GGE biplot. Crop Breeding and Applied Biotechnology, 10, 247-253. https://doi.org/10.1590/S1984-70332010000300010

Petri, J. L., Hawerroth, F. J., \& Leite, G. B. (2008). Phenology of wild apple species like pollinators of gala and fuji cultivars. Revista Brasileira de Fruticultura, 30, 868-874. https://doi.org/10.1590/S0100-2945200 8000400005

Pio, R., Bueno, S. C. S., Maro, L. A. C., Bueno, J. P. S., \& Assis, C. N. (2014). Maturation season, physics and chemical characterization of chestnut cultivars and selections. Revista Brasileira de Fruticultura, 36, 525-531. https://doi.org/10.1590/0100-2945-254/13

Pio, R., Melo, E. T., Bueno, J. P. S., Silva, L. F. O., Peche, P. M., \& Curi, P. N. (2017). Seminiferous propagation in the selection of chestnut tree rootstocks. Ciência Rural, 47, 1-5. https://doi.org/10.1590/0103-8478c r20161010

Pio, R. (2018). Cultivo de fruteiras de clima temperado em regiões subtropicais e tropicais. $2^{a}$ Edição Revisada e Ampliada (2nd ed., p. 681). Lavras-MG: Editora UFLA.

Pio, R., Souza, F. B. M., Kalcsits, L., Bisi, R. B., \& Farias, D. H. (2019). Advances in the production of temperate fruits in the tropics. Acta Scientiarum. Agronomy, 41, 1-10.

Souza, F. B. M., Alvarenga, A. A., Pio, R., Gonçalves, E. D., \& Patto, L. S. (2013). Fruit production and quality of selections and cultivars of peach trees in Serra da Mantiqueira, Brazil. Bragantia, 72, 133-139. https://doi.org/10.1590/S0006-87052013005000024

Vossen, P. (2000). Chestnut Culture in California. ANR Publications. https://doi.org/10.3733/ucanr.8010

Yamanishi, O. K., Sobierajski, G. R., Bueno, S. C. S., \& Pommer, C. V. (2010). Chestnut in Brazil: researches and perspectives. Acta Horticulturae, 866, 539-541. https://doi.org/10.17660/ActaHortic.2010.866.73

Yan, W, Hunt, L. A., Sheng, Q. L., \& Szlavnics, Z. (2000). Cultivar evaluation and mega-environment investigation based on the GGE Biplot. Crop Science, 40, 597-605. https://doi.org/10.2135/cropsci2000. $403597 x$

Yan, W., \& Rajcan, I. (2002). Biplot evaluation of test sites and trait relations of soybean in Ontario. Crop Science, 42, 11-20. https://doi.org/10.2135/cropsci2002.0011

Yan, W., \& Kang, M. S. (2003). GGE biplot analysis: A graphical tool for breeders, geneticists, and agronomists (p. 286). Flórida: Boca Raton.

Yan, W, \& Tinker, A. (2006). Biplot analysis of multi environment trial data: Principles and applications. Canadian Journal of Plant Science, 86, 623-645. https://doi.org/10.4141/P05-169

Zenginbal, H., Ertürk, U., Koşar, M. B., \& Ahi, D. (2018). Evaluation of chestnut genotypes from Düzce vicinity, Turkey. Acta Horticulturae, 1220, 29-34. https://doi.org/10.17660/ActaHortic.2018.1220.5 


\section{Copyrights}

Copyright for this article is retained by the author(s), with first publication rights granted to the journal.

This is an open-access article distributed under the terms and conditions of the Creative Commons Attribution license (http://creativecommons.org/licenses/by/4.0/). 